Agro-Science Journal of Tropical Agriculture, Food, Environment and Extension Volume 20 Number 2 (April 2021) pp. 1 - 8

ISSN 1119-7455

\title{
TRACTOR USE AND AGRICULTURAL PRODUCTIVITY IN NIGERIA: PROSPECTS AND CHALLENGES
}

\author{
"Umar M.B., Yarima M.M., Yusuf O.E., Adetayo A. and Salihu M. \\ Department of Agricultural Economics \& Extension, \\ Federal University Dutse, Ibrahim Aliyu By-Pass, PMB 7156, Dutse, Jigawa State, Nigeria \\ *Corresponding author's email: umarmukhtar79@gmail.com
}

\begin{abstract}
The objectives of this study were to examine the role of tractor use in agricultural mechanisation, explore the prospects of tractor use in Nigeria and identify the challenges of tractor use in agriculture in Nigeria. The study adopted literature review; whereby secondary data have been used. The assumption of the study was that improvement in farming is directly connected with improvement in farmer's income and livelihood. Also, that mechanised agriculture is necessary for productivity, and by implication increases profit in farm production. Tractor is one of the major farm tools that enhance mechanisation in agriculture. Therefore, incorporating the mechanisation, notably tractor is essential because it affects the farmer's livelihoods and living conditions. The finding of the study indicated that tractor plays significant role as it is established that crop-production increased through tractor use, which increased the farmers' income, giving room for increased production capacity thereby enabling the farmers to settle some of their outstanding debts. The study also found that tractor has prospect in Nigeria because recent development in economic diversification which emphasised agribusiness in the country portends movement towards application of intensive farm labour. However, there are some noticeable challenges associated with tractor use in Nigeria. One of these challenges is un-affordability because tractor use is very costly. Other challenges are under-utilisation, lack of knowledgeable personnel to manage the tool, lack of spare parts; and government-run tractor hire schemes are not effective because they are in a state of collapse. The study therefore concluded that tractor use is a necessary evil in Nigeria, because despite its displacement tendency and cost, the increasing population of Nigeria calls for investing in mechanised agriculture for increasing productivity, improving farmers' income and livelihood, and above all achieving food security.
\end{abstract}

Key words: agricultural mechanisation, productivity, Nigeria, tractor

\section{INTRODUCTION}

Nigeria is the most populated African country, having an estimated population of more than 190 million people (ITA, 2018). This signifies that the country is a large potential market for agriculture, because the agricultural produce can be restricted to satisfying internal market and surplus can also be exported for the international markets. To this end, Nigerian farmers should adopt mechanised agricultural production. This is instructive because agricultural mechanisation is a necessary enterprise for maximum productivity, competitive advantage and effective value chain. In other words, mechanisation has a big potential for increased agricultural productivity in a large population, such as Nigeria. The main reason why mechanisation may achieve an increase in productivity is corroborated by Maina (2004), who noted that when farm labour is used in combination with any form of mechanisation, it enables the completion of a greater amount of work per unit time.
The costs and benefits of mechanised agriculture and other forms of farm power, over manual labour have already been appreciated by both farmers of developed and developing countries (IITA, 2018). In fact, since 200 years ago, nearly every parts of the developed world have seen an agricultural transformation (Bill and Melinda Gates Foundation, 2011). In Nigeria, however, smallholder farmers do not have access to mechanised forms of farm labour, such as ownership of tractors, nor can the majority of them afford to even hire its services. For some of them, the only means of access is through a tractor service provider who will service their land for a fee, whereby they are charged per hectare or per hour. The problem is not only that there are too few of the hired service providers to meet the demand of the growing numbers of farmers in Nigeria, the vast majority of poor farmers cannot afford to pay the service fee. 
More so, women are more affected by lack of agricultural productivity in Nigeria. Bill and Melinda Gates Foundation (2011) reported that women are vital contributors to farm work in Nigeria and other sub-Saharan African countries. They are typically in charge of selecting food for, and feeding their families. Yet compared to their male counterparts, women farmers are less productive and unable to reach their full potential. Yields on women's plots are typically 20 to $40 \%$ less than men's, putting rural families and communities at risk of not having enough nutritious food to eat or any extra to sell at the market. This is a negative development that should be addressed for the Nigerian farmers to increase per capita productivity and produce more yields. To achieve, both male and female farmers should optimally utilise modern method of land preparation and harvesting through mechanisation, notably the use of tractor.

There are many previous studies on agricultural mechanisation, especially tractor use (Bojnec et al., 2003; PrOpCom, 2009; PrOpCom, 2011; Schmitz and Moss, 2015). But these studies have tended to be narrowly focused, by restricting themselves to one specific area, like farm power mechanisation, draught animal power, hand tool technology, etc. Bojnec et al. (2003) acknowledged the existence of farm owner and farm worker but they expressed no concern about the problem of displacement and compensation, as they stated that "within agricultural employment, the category of the farmer and the employee in an individual farm is the most important employment category, but its importance declines over time". As for those who discussed the problem of displacement, only PrOpCom (2011) showed concern on animal labour displacement by the tractor, while turning a blind eye on displacement of human labour, which is more alarming. Displacement of animal labour will only mean displacement of job opportunities since cattle owners can get alternative opportunity other than the farm labour, such as transporting goods. This calls for the conduct of studies that examine the fate of displaced unskilled agricultural workers in Nigeria so that policies will be geared towards evolving systematic schemes that can empower them. PrOpCom (2011) ignored the plight of displaced farm labourers, while Schmitz and Moss (2015) discussed issues related to farm workers displaced by mechanisation.

In other words, these studies dealt with tractors, draught animal, or with intermediate technology, but ignored the overall subject of mechanisation. Where the topic of farm power and mechanisation are considered, such studies also tend to be separated from the actual process of growing crops. These gaps could lead to widespread lack of understanding of the topic and misconceptions regarding the essential contribution of farm power and mechanisation to small farmers in Nigeria. Bill and Melinda Gates Foundation (2011) and Schmitz and Moss (2015) have pointed out that improvement in farming is directly connected with improvement in incomes, health, and economies. Consequently, studies incorporating the farm power and mechanisation are essential because they affect the farmer's livelihoods and living conditions.

In view of the above, this study was aimed at investigating the role of tractor in agricultural productivity in Nigeria. The specific objectives were to (i) examine the role of tractor use in agricultural mechanisation in Nigeria, (ii) explore the prospects of tractor use in Nigeria, and (iii) identify the challenges of tractor use in agriculture in Nigeria.

The article is structurally divided into seven sections: section one is the introductory part; section two provides conceptual clarifications of agriculture, agricultural mechanisation and agricultural productivity; section three deals with theoretical framework; section four discusses the roles of tractor use in agricultural mechanisation; section five covers the challenges of tractor use in agriculture in Nigeria; section six concludes the article; and section seven provides some recommendations.

Conceptual Clarifications of Agriculture, Agricultural Mechanization and Agricultural Productivity Agriculture: Agriculture has been defined depending on its sub-discipline or on its whole scope. Bareja (2014) defined agriculture as the art and science of growing plants and other crops as well as raising animals for food and other human needs, or economic gain. In addition to incorporating economic gain (a pivot to economic diversification and economic development), the above definition describes agriculture as both an art and a science. This, according to Bareja (2014), is because the agricultural practice needs skills and it is founded on scientifically verified facts. The words "growing" and "raising" signify that the agriculture has two broad divisions: plant or crop production and animal or livestock production. The ultimate purpose of agriculture is to produce food, while other human needs, such as clothing, medicines, shelter, and economic profits are attained (Mukhtar and Mukhtar, 2017).

The major agricultural products can be broadly grouped into foods, fibres, fuels and raw materials. In the 21st Century, plants have been used to grow biofuels, biopharmaceuticals, bioplastics and pharmaceuticals (Sharma 2013; Mukhtar et al., 2014; Mukhtar and Mukhtar, 2017). Specific foods, according to Sharma (2013), include cereals, vegetables, fruits, and meat. Fibres include cotton, wool, silk and flux. Raw materials include lumber and bamboo. Biofuels include methane from biomass, ethanol, and biodiesel; cut flowers, nursery plants, tropical fish and birds for the pet trade and some of the ornamental products. 


\section{Mechanised Agriculture}

Mechanised agriculture is the use of machinery and equipment to make agricultural work easier and faster in order to increase efficiency and productivity (CRIT, 2012). In modern times, powered machinery has replaced many jobs formerly carried out by men or animals such as oxen, horses and mules. The level, appropriate choice and subsequent proper use of farm machinery and equipment in agriculture has a direct and significant effect on achievable levels of land productivity, labour productivity, profitability of farming, the environment and the quality of life of people engaged in agriculture (CRIT, 2012). Mechanisation in many countries has dramatically reshaped the agricultural landscape since the time of early settlement. The introduction of new technologies like large fourwheel-drive tractors has resulted in increase in both farm size and agricultural output, and a decrease in the demand for farm labour.

In technologically advanced countries, such as the United States and Canada the use of mechanical tomato harvester, grain combines, and-today's agricultural mechanisation that includes information technologies and precision agriculture led to the demise of rural communities (Schmitz and Moss, 2015). Consequently, Schmitz and Moss (2015) argued that the adoption of new technologies results in losers and gainers, because some of the earliest mechanical innovations in agriculture involved the replacement of draft animals with the steam engine power, which was replaced by the internal combustion engine.

\section{Agricultural Productivity}

Agricultural productivity is a measure of the amount of agricultural output produced for a given amount of inputs, such as an index of multiple outputs divided by an index of multiple inputs, e.g., the value of all farm outputs divided by the value of all farm inputs (Michel Cherris Institute, 2012). According to Johnson (2007), agricultural productivity is the term given to the output of agriculture in terms of the inputs such as the capital and labour. Therefore, as a fairly general comment, this could be defined as the efficiency of the farm. Agricultural productivity varies in different parts of the world, and this can be put down mainly to the amount of capital the farm owner has. Although there are other factors involved a lot of them are dependent on the amount of capital available. In economically developed countries, farms are largely owned by wealthy people who can afford to buy machinery. This enables the farm to run more efficiently as the processes on the farm can be completed at a quicker rate and therefore the labour efficiency becomes better as one person can perform more work in one day than if no machinery was available. This saves the employee money as less staff to be hired so therefore the wage bill is lower (Johnson, 2007).
In contrast, farmers in many less developed countries are into subsistence agriculture, as they produce to provide food for the family, and not primarily to create a profit (although this may occur during a good harvest). Therefore, so long as the farmer has enough labour and land to grow enough food for his family he will not try to increase the productivity. This means that it is highly likely that the productivity of farms in economically developed countries is going to be higher than that of less economically developed countries (Johnson, 2007). Failure to adopt mechanised agriculture has culminated in stagnation and decline in agricultural productivity being felt throughout much of Africa and South Asia (Johnson, 2007).

Today, the average farmer in Sub-Saharan Africa gets just over a ton of cereal per acre, while the average Indian farmer gets about twice that, the average Chinese farmer about five times, and the average American farmer about seven times that amount. Why is there such disparity? Farmers in other regions have tools, techniques, and resources that farmers in Africa do not (Belinda and Melinda Gates Foundation, 2011). As argued by Johnson (2007), the amount of productivity is highly reliant on what the farm is used for. As shown in the example above, productivity will be lower if the intention is not to make money. However, when the intention is to make money as in many instances in developed countries as well as in some developing countries like Nigeria, where companies have set up businesses, the farmer will try to exploit his/her land as much as he/she can so that it can become as efficient as possible.

\section{Theoretical Framework}

There are many propositions about tractor use in Nigeria. Some of these grounded theories have argued that tractor use has positive impact on the income earning of farmers for a number of such benefits as cost-saving, expansion of farmland and maximum productivity (Sims and Kienzle, 2006; PrOpCom, 2009; Paman et al. 2010; Olaoye and Rotimi, 2010; PrOpCom 2011; Isa, 2015; Takeshima, 2016; IITA, 2018). Other studies (Mijinyawa and Kisaiku, 2006; Oluwole and Odogola, 2018) have shown that tractor use have not much benefited small holder farmers in Nigeria because this particular set of farmers have to rely on hiring, which is marred by managerial cost, cost of hiring, wear and tear as the tractors are largely aged, while some are totally not operating at all.

According to Michel Cherris Institute (2012), the index-number approach to studying productivity estimates total factor productivity (TFP), which measures levels and changes in agricultural output relative to changes in an aggregated index of multiple inputs. Labour productivity in agriculture is work produced by unit 
of time, understood as economic efficiency. Productivity is intimately linked with knowledge, and technology, organisation, governance skills. Also needs to be considered in the frame of nowadays include globalisation, competition, and profit maximisation. Michel Cherris Institute (2012) has precisely stated that agricultural productivity is the ratio (expressed in volume or monetary units) between the production (outputs, such as goods or services) and the resources employed (inputs, such as work, capital) to generate what is produced.

Bearing in mind that farm power must be an essential ingredient of agricultural productivity and livelihoods strategies to Nigerian farmers, two approaches to satisfying the need have been highlighted by Sims and Kienzle (2006): on one hand, increasing the supply of farm power, and on the other, reducing the need for it. Examinations of the demand for tractor clearly show that the greatest demand comes from land preparation, and as has been indicated, this is also the source of greatest environmental degradation. However, there is now crucially important evidence that traditional land preparation methods may not be necessary and that conservation tillage, including zero tillage, can provide an alternative that is economically and ecologically sustainable.

\section{Role of Tractor Use in Agricultural Mechanisation} The role of tractor use in agricultural mechanisation and productivity cannot be over emphasised world over. This is because agriculture plays a significant role in the Nigerian economy and accounts for a substantial proportion of its total economic activity, with over $70 \%$ of her population depending on it directly or indirectly as a means of livelihood (CRIT, 2012). Between 2003 and 2007, the average share of agriculture's contribution to national real GDP was $41.5 \%$, out of which, crop, livestock, fishery and forestry sub-sectors contributed $90 \%$, $6 \%, 3 \%$ and $1 \%$, respectively (FGN, 2010). Thus, the crop production sub-sector is the key source of agricultural growth in Nigeria (CRIT, 2012). The vital role of agriculture in the Nigerian economy makes it necessary for the agriculture sector to be reinvigorated in order to achieve food security. This will lead to improved quantity and quality of food per person as well as the well-being of farmers and all citizens of Nigeria (CRIT, 2012).

Many studies have discovered that tractor improves productivity, and increases farmers' output, thereby increasing their income through cost-saving methods of farming. In his study in Bauchi and Yobe States, Isa (2015) established that crop-production increased through mechanisation, the notable of which is tractor, and resulted in increase in income of the farmers thereby given room for increased production capacity thereby enabling the farmers to settle some of their outstanding debts. Crop-producing farmers' standard of living improved because of the use tractor and other mechanised mode of crop production in the study area.

To finance lump sum investments from cash inflow requires saving up, and this is only possible if the business operations are sufficiently profitable to leave a margin that can be saved, after meeting household and routine business expenditure (Sims and Kienzle, 2006). Takeshima (2016) combined short-term expenditures ( 7 days and 30 days) from the post-planting survey and long-term expenditures (6 months and 12 months) from post-harvesting survey. This is because the researcher's interest is on the expenditure immediately following the planting season when tractors are typically used. Using short-term expenditures from the postplanting survey instead of the post-harvesting survey ensures that these expenditures more clearly reflect the cost savings realised from using tractors instead of labour in the planting season.

The need for sustained government support in the promotion of agricultural mechanisation and service market (as well as ready access to other essential farm inputs) has never been in doubt, especially considering the preponderance of smallscale, smallholder producers and market players, vis-à-vis the generally harsh economic environment. However, the nagging concern has always been and continues to be about how really pro-poor public spending on agricultural mechanisation is, and which groups in the population have been benefiting and stand to benefit most from government-financed agricultural mechanisation subsidy support. Under the much-talked-about private sector-led community cooperative tractor hiring scheme initiated by government would contribute $40 \%$ subsidy on the cost of tractors ( $25 \%$ by FGN and $15 \%$ by state governments), with private sector operators providing the balance of $60 \%$. The intention is to procure a total of 10,000 tractors and implements during the 3-year period 2008-2011. With the planned procurement of 3,525 additional/ new tractors and implements in 2009, the cost to FGN in subsidy (25\%) is estimated at 6.5 billion. As earlier inferred, such a huge level of expenditure is a welcome temporary measure, so long as the strategy is to support viable private sector-led agricultural mechanisation markets. However, it is noted that no similar deliberate intervention is planned for animal-powered technologies, postharvest operations and the processing of agricultural commodities (PrOpCom, 2011).

There is a disturbing development in the Nigerian agriculture related to labour, which is one of the main factors of agricultural production: the shortage of manual labour input in the agricultural sector of the economy because farmers are increasingly tired of exerting manual power 
(Oladeji et al., 2012). Shortage of labour should be of great concern to all considering the fact that Nigeria agriculture is in the hands of the peasant farmers who rely on manual labour. Agricultural practice is carried out by smallholder farmers cultivating 2-3 hectares of farm holdings using human labour and simple hand tools. In order to avert the devastating effect of inadequate supply of labour on our agriculture, especially at the village level, looking in the ways of technologies that are capable of reducing heavy dependence on manual labour may be the right focus. With the current rates of population growth, the main way to avoid food shortage in African countries is to focus attention on technologies that could raise productivity of labour. This suggests that the logical answer to shortage of hands on the farm is mechanisation or hand operation that could be mechanised provided it would be profitable to the farmers. The use of tractors and farm animals, for example, requires a few hands (Oladeji et al., 2012).

As reported by PrOpCom (2011) on relatively level, unobstructed land, manual labour is generally less thorough than mechanised equipment. Given the physical nature of the work, a hoe labourer will be tired as the day progresses, with diminishing returns to time spent on the farm. The soil is turned to reduced depths, broken down less, and in the case of ridging, the spacing between rows increases in order to complete the plot quickly. All these elements reduce the quality of the seedbed and the potential size of the standing crop, substantively reducing yields. In line with the above, Oladeji et al. (2012) observed that shortage of labour is a great concern considering the fact that Nigeria agriculture is in the hands of the peasant farmers who rely on manual labour. Agricultural practice is carried out by small holder farmers cultivating between 2-3 hectares of farm holdings using human labour and simple hand tools. Although dilemma surrounds the economic life of the rural farmers in Nigeria, making it necessary to employ manual labour in the cultivation of farmland, human labour is not favourable to these small holding farmers.

\section{Prospects of Tractor Use in Nigeria}

Nigerian farmers like their counterparts in other developing countries are interested in improving their income, life style and general well-being. That is why Nigerian farmers consider the adoption of tractor use and other advanced technologies if it will serve as a means for achieving these objectives. The performance of tractor in agriculture sector has been noteworthy everywhere in the world, Nigeria inclusive. This is because application of improved technologies and the land productivity are positively correlated (Abubakar and Ahmad, 2010; Sims and Kienzle, 2016). Recent development in economic diversification which emphasised agribusiness in Nigeria portends movement towards application of intensive farm labour. The need for massive production of rice and other domestically grown agricultural products means that large farm lands must be used (Obalum et al.,2014), which also has an implication on farm power. There is massive involvement of both rural and urban Nigerians in agriculture in the last 3-4 years (IITA, 2018).

There is implication of involvement of more urban population in agriculture in Nigeria because it resulted in the emergence of more large-scale farmers, because using tractors indicates larger crop production. It can also affect the labour supply in the country. According to (IITA, 2018), Nigerian economy took a hit from declining oil revenues in 2015 , forcing the government to seek economic diversification. It has set to pursue agricultural development as one of its key goals to help address the country's dependence on food imports totalling nearly 11 billion dollars annually. It has also engaged in a campaign to redirect focus from oil to agriculture, manufacturing and solid minerals development. In this regard, the government has rolled out five agricultural development initiatives. They include the Anchor Borrowers Programme (ABP), the Presidential Fertiliser Initiative (PFI), the Youth Lab, the Presidential Economic Diversification Initiative (PEDI) and the Food Security Council. The ABP for example, was created by the Central Bank of Nigeria and works in partnership with state governments and several private sector groups to provide farm inputs in kind and cash to small holder farmers to boost production of agricultural commodities. At harvest, the farmers supply their produce to the agroprocessors (anchor) which pays the cash equivalent to the farmers' account. According to government reports, under the $\mathrm{ABP}$ initiative, a cumulative amount of over 150 million dollars has been disbursed to more than 250,000 small farmers who cultivated almost 300,000 hectares of farmland for rice, wheat, maize, cotton, soybeans, and cassava. This growing trend of agricultural activity is expected to continue, thus creating demand for agricultural inputs (IITA, 2018).

According to PrOpCom (2011), recent years have witnessed a surge in the daily rates of casual labour, from $\$ 200 \mathrm{day}^{-1}$ ( $£ 0.75$ ) to approximately $\$ 500$ day $^{-1}$ (£2) in the most severely affected states. The average costs associated with manually

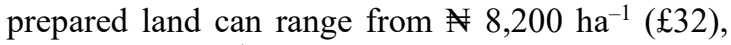
or $\$ 9,600 \mathrm{ha}^{-1}$ (£39) with an ox-plough, to $\$ 11,400 \mathrm{ha}^{-1}$ (£44) in the north and southwest respectively. Relative to this, the cost of hiring a private tractor for land preparation is less expensive, estimated at $\$ 6,000 \mathrm{ha}^{-1}$ (£23) in the states of the north, and $\$ 7,500 \mathrm{ha}^{-1}$ (£29) in the south-western states. As observed by Olaoye and Rotimi (2010), with tractorisation has a direct and significant effect on achievable levels of land productivity, labour productivity, the profitability 
of farming, the sustainability, the environment and, on the quality of life of people engaged in agriculture. Hence Paman et al. (2010) suggested that tractor annual use should be increased to reduce costs or augment profit. The use of tractor for custom hire service should be promoted for augmenting farmers' income and developing tractor ownership in the province.

Originally, the early tomato industry was 80 $90 \%$ dependent on immigrant labour. A study by de Janvry et al. (as cited in Schmitz and Moss, 2015) found out that the adoption of the tomato harvester appeared to be the only alternative when the Bracero programme ended in 1964. From the tomato grower's perspective, switching to mechanical harvesting required a large initial investment. Consequently, the adoption of the tomato harvester caused a shift from the variable cost of hand harvest to the high fixed cost of mechanisation. Growers were willing to make this investment because of the support from processors in the pricing of tomatoes. Furthermore, switching to mechanical harvesting yielded an estimated cost savings of between $\$ 5.41$ and $\$ 7.47$ per ton to growers. These savings were attributable to machines only requiring one pass through the field and machine sorters being paid less than hand pickers. Due to the larger capital investment required to purchase machinery, growers implemented larger-scale planting to increase yields to offset larger overhead investment costs (Schmitz and Moss, 2015). Because planting a single crop would have incurred a higher risk due to vulnerability to market fluctuations and weather, only farmers with sufficient land for other crops could afford to take on the risk of growing tomatoes. Consequently, large-scale planting eventually led to a situation whereby there were fewer growers with larger acreages.

Challenges of Tractor Use in Nigeria Agriculture The previous section has discussed the prospects of tractor use in Nigeria, but it also has many challenges. One of the most obvious challenges of tractor in Nigeria is its un-affordability because tractor use is very costly (Oluka, 2000). Government-run tractor hire schemes in developing countries of Africa are not widely effective and therefore in a state of collapse today following a reduction in government expenditure on services that could, theoretically, be provided by the private sector. Private sector tractors have been profitable on large landholdings, but they have seldom proved viable for the smallholder sector whether in individual or group ownership; or in private hire services in countries like Nigeria (Sims and Kienzle, 2006).

In the same vein, Oluwole and Odogola (2018) observed that there are some other challenges associated with the tractor use in Nigeria, such as under-utilisation by vast majority of Nigerian farmers, lack of knowledgeable personnel to manage the equipment, cost of the equipment, lack of spare parts and largely, the running of the programme by the government civil service system. According to the data emanating from World Bank (cited in (PrOpCom, 2011), the average number of tractors per $100 \mathrm{~km}^{2}$ of arable land in Nigeria is 6.8, compared to 26.9 in Kenya and a world average of 195.3. With just over 30 million ha of land under cultivation, Nigeria is a home to somewhere in the region of 20,000 public and private tractors, though not all of these tractors are in constant working order, nor are they available throughout the season (PrOpCom, 2011). This falls significantly short of the numbers required, even under conservative estimates.

Recent development efforts have seen the importation and use of smaller tractors from some Asian countries. The two-wheeler motorised equipments are gaining grounds especially in the regions where animal traction is not effective due to livestock failure (Oluwole and Odogola, 2018). Given that one tractor can service an average of 137 smallholders in the course of a typical year (some of these may be the same smallholder twice if they double-season crop) and that approximately $60 \%$ (9.6 million) of the nation's 16 million smallholders could be legitimate potential customers for a tractor service provider, there would need to be over 70,000 tractors distributed relatively evenly across the country, and readily available for hire, before the market begins to meet potential demand. Also, $100 \%$ of respondents in PrOpCom's survey of private tractor service providers believed that the supply of services did not meet the demand (PrOpCom, 2011).

The foregoing statistics have indicated that getting adequate tractors that can suffice the magnitude of the large number of Nigerian farmers is not too soon. It is therefore instructive to maintain the animal power which is a renewable and to promote patronage for the service of tractor providers in Nigeria. One notable service providers surveyed by PrOpCom (2009) can serve as an impetus for participating in such tractor services. The survey reported that the tractor service providers that participated in the Springfield-First Bank-TOOAN (Tractor Owners and Operators Association of Nigeria) pilot $(n=19)$ are more profitable in both the peak and the low seasons than the tractor service providers that did not participate $(n=30)$, once the servicing of loan repayments are stripped out. In the north, gross profits for participating service providers are a substantial $\$ 814,000$ ( $£ 3,170$ ) higher in peak season and $\$ 218,600$ ( $£ 850$ ) higher in the low season. In the southwest, the difference is narrower, but still significant, at $\$ 426,900(£ 1,725)$ and $\$ 66,650$ (£270), respectively. 
The issue of labour displacement is another challenge and has been questioned by scholars. According to Hart Sough (as cited in Schmitz and Moss, 2015), the mechanical harvesting of tomatoes was controversial because it seemingly displaced human labour. However, by reducing harvesting costs by nearly one-half, the harvester eliminated an economic constraint on the US tomato processing industry, resulting in large increases of tomato acreage and yield. Those increases, in turn, provided additional employment in field work, transportation, and processing that more than offset the displaced harvesting jobs.

\section{CONCLUSION}

The paper has examined the role, prospects and challenges of tractor use in agricultural productivity in Nigeria. It has been established that tractor use has drastically improved farmers' income and livelihood through maximum productivity. It has also showed that the Nigeria's journey to economic diversification through reinvigoration of mechanisation implies the need for more tractor use in the country. Yet, some challenges associated with tractor are obvious. For example, the cost of the machine will deprive many smallholder farmers from optimum utilisation of tractor in Nigeria. In addition, lack of well skilled personnel to manage it have posed serious challenges to the entire prospect of agriculture sector in Nigeria. However, it is the responsibility of the government to make tractor available for the vast majority of Nigerian farmers if the country is truly prepared to revitalise the agriculture sector. The study therefore concluded that tractor use is a necessary evil in Nigeria, because despite its displacement tendency and cost, the increasing population of Nigeria calls for investing in mechanised agriculture for increasing productivity, improving farmers' income and livelihood, and above all achieving food security.

Based on the findings of the study, the article made the following recommendations:

1. It is instrumental for the government and other non-governmental bodies to intervene (making more tractors available and affordable for all categories of farmers) on the use of tractor by the Nigerian farmers because technological advancement must be encouraged;

2. The Nigerian government should be prepared for compensating displaced workers through special empowerment scheme and alternative job opportunities (training on agro-processing and agripreneurship skills which would benefit the youth understand the market and develop own business plans, etc.);
3. To make tractor available, the government should find means of subsidising the cost of tractor hiring and the cost in most aspect of agricultural production, from seed purchase, cultivating, ploughing, harrowing, fertiliser, to harvesting; and

4. There is the need for the government to produce more trained engineers or personnel who can handle tractors with proficient care. These managers can be sponsored to study abroad, in China, India or US on how best to manage the tractors for longevity, effectiveness and efficiency.

\section{REFERENCES}

Abubakar M.S. and Ahmad D. (2010). Utilisation of and constraints on animal traction in Jigawa State, Nigeria. Australian Journal of Basic and Applied Sciences, 4 (6), 1152-1156

Bareja B.G. (2014). What is agriculture, definition of agriculture. Retrieved from: http://www.cropsreview. com/what-is-agriculture.html (Accessed on: 3/05/2019)

Bill and Melinda Gates Foundation (2011). Agricultural development strategy overview. Retrieved from: www.gatesfoundation.org

Bojnec S., Dries L. and Swinnen J.F.M. (2003). Human capital and labor flows out of the agricultural sector: Evidence from Slovenia. Proceedings of the 25th International Conference of Agricultural Economists (IAAE), from 16-22 August, Durban, South Africa

CRIT (2012). Issues in mechanised farming in Nigeria. Consultancy, Research \& Information Technology (CRIT). Industrial Training Fund (ITF) Headquarters, Jos

FGN (2010). Review of On-Going Agricultural Development Efforts. Federal Government Nigeria

ITA (2018). Nigeria - Agriculture. International Trade Administration. United States Department of Commerce. https://www.export.gov/ITA (Accessed on: 23/04/2019)

Isa M. (2015). Influence of Agricultural Mechanisation on Crop Production in Bauchi and Yobe States, Nigeria. MSc Thesis, Department of Vocational \& Technical Education, Ahmadu Bello University, Zaria

Johnson M. (2007). Define the term agricultural productivity and describe how it varies between different parts of the world. Agriculture Essay. Retrieved from: http://www.markedbyteachers.com/ as-and-a-level/geography/define-the-term-agricultural -productivity-and-describe-how-it-varies-betweendifferent-parts-of-the-world.html (Accessed 05/05/2019)

Maina P.G. (2004). The Effect of Using Animal Traction on Farm Efficiency and Household Labour Allocation on Smallholder Farms in Kenya: A Case of Kirinyaga District. MSc in Agricultural Economics of the University of Nairobi

Michel Cherris Institute (2012). Agricultural productivity, resources and related matters. Retrieved from: http://institutmichelserres.ens-lyon.fr/spip.php?article39 (Accessed on: 4/05/2019)

Mijinyawa Y. and Kisaiku O.O. (2006). Assessment of the Edo State of Nigeria tractor hiring services. Agricultural Engineering International: the CIGR EJournal. Invited Overview Paper, No. 8, Vol. VIII 
Mukhtar J.I. and Mukhtar H.Y. (2017). Agricultural revitalisation: a catalyst for economic diversification in Nigeria. In: Fagge A.M. and Ahmed B.A. (eds.) Readings in Economics: Diversification of the Nigerian Economy Department of Economics and Development Studies, Federal University Dutse

Mukhtar U., Mukhtar J.I. and Abdullahi M.A. (2014). Revitalisation of agriculture as a strategy for reducing poverty in Nigeria. International Journal of Research in Social Sciences, 4 (4), 429-440

Obalum S.E., Watanabe Y., Igwe C.A., Obi M.E. and Wakatsuki T. (2014). Puddling intensity for late-season sawah systems based on soil hydrophysical conditions and rice performance. International Agrophysics, 28, 331-340. DOI: 10.2478/intag-2014-0023

Oladeji J.O., Ogunleye K.Y. and Aderinto A. (2012). Attitude of farmers towards the use of animal traction technology in Savannah Zone of Oyo State, Nigeria. Global Journal of Science Frontier Research Agriculture and Veterinary Sciences, 12 (8), 16-23

Olaoye J.O. and Rotimi A.O. (2010). Measurement of agricultural mechanisation index and analysis of agricultural productivity of some farm settlement in South-West, Nigeria. Agricultural Engineering International: the CIGR Ejournal. Manuscript 1372. Vol XII

Oluka S.I. (2000). Costs of tractor ownership under different management systems in Nigeria. Nigerian Journal of Technology, 19 (1), 15-23

Oluwole F. and Odogola R. (2018). Status of smallholders agricultural mechanisation in sub-Saharan Africa. Forum for Agricultural Research in Africa, 2 (10), 27
Paman U., Uchida S. and Inaba S. (2010). The economic potential of tractor hire business in Riau Province, Indonesia; A case of small tractor use for small rice farms. Agricultural Engineering International: the CIGR Ejournal, 12, 1-12

PrOpCom (2009). Public sector investment in support of agricultural mechanisation in Nigeria. Making Nigerian Agricultural Markets Work for the Poor, Monograph Series Vol. 44, Abuja, Nigeria

PrOpCom (2011). Making tractor markets work for the poor in Nigeria: A PrOpCom case study. PrOpCom. Abuja, Nigeria. www.propcom.org

Schmitz A. and Moss C.B. (2015). Mechanised agriculture: Machine adoption, farm size, and labour displacement. The Journal of AgroBiotechnology Management and Business, 8 (3), 6

Sharma R. (2013). Rice Cultivation and Processing. Discover Publishing House, PVT Ltd, New Delhi

Sims B. and Kienzle J. (2006). Farm power and mechanisation for small farms in sub-Saharan Africa. Agricultural and Food Engineering Technical Report, 3. Food and Agriculture Organisation (FAO) of the United Nations, Rome

Sims B. and Kienzle J. (2016). Making mechanisation accessible to smallholder farmers in Sub-Saharan Africa. Environments, 3 (11), 1-18. DOI:10.3390/environments3020011

Takeshima H. (2016). Market imperfections for tractor service provision in Nigeria. Nigeria Strategy Support Programme. Working Paper 32 